DOI: $10.17805 /$ trudy.2017.3.7

\title{
ИЗ ИСТОРИИ ВОЗНИКНОВЕНИЯ ПОНЯТИЯ ПЕДАГОГИЧЕСКОГО МЕНЕДЖМЕНТА В РОССИИ
}

\author{
Е. С. Харченко \\ Московский гуманитарный университет
}

\begin{abstract}
Аннотация: В статье рассматривается педагогический менеджмент как особый вид деятельности, в центре которой лежит взаимодействие между субъектами образовательной деятельности и гармоничные отношения между ними.
\end{abstract}

Ключевые слова: педагогический менеджмент; управление образованием; гуманное отношение

\section{FROM THE HISTORY OF THE NOTION OF PEDAGOGICAL MANAGEMENT IN RUSSIA}

\author{
E. S. Kharchenko \\ Moscow University for the Humanities
}

Abstract: This article deals with pedagogical management as a special activity in the centre of which lies the interaction between subjects of the educational activity and harmonious relationship between them.

Keywords: pedagogical management; management of education; humane attitude

Согласно действующему закону «Об образовании в Российской Федерации» (2012 г.), образование есть «целенаправленный процесс воспитания и обучения в интересах человека, общества, государства» (Федеральный закон ..., Электр. ресурс). Для эффективной реализации этого процесса необходимо осмысление его целостности с точки зрения науки управления и придание ему научно обоснованных признаков.

Управление системой образования включает в себя такие аспекты, как формирование системы взаимодействия органов федеральной, исполнительной власти и органов местного самоуправления; стратегическое планирование системы образования; реализацию программ, направленных на развитие системы образования; мониторинг в системе образования; государственную регламентацию образовательной деятельности; аккредитацию и оценку качества образования; подготовку и повышение квалификации работников образования. 
Закон об образовании, принятый в нашей стране в 1973 г., также рассматривал аспект руководства образованием, которое осуществлялось органами государственной и муниципальной власти, в том числе в республиках, областях. В их функции входила разработка общих положений в области организации и контроля функционирования учебновоспитательных учреждений. Следует отметить, что особое внимание уделялось укреплению связи образования и воспитания с производственной сферой и жизнью, определению профиля трудовой подготовки школьников, и организации их трудового обучения в соответствии с потребностями народного хозяйства в кадрах, а также трудоустройство выпускников. Важная роль отводилась руководству дошкольным и школьным воспитанием и оказанию содействия в области воспитания.

В последние десятилетия в современной России появляется достаточно новое для отечественной системы образования понятие «педагогический менеджмент», которое привносит новое содержание в систему взаимодействия «человек - человек».

Термин «менеджмент» заимствован от английского management управление, руководство, администрирование, дирекция, умение распоряжаться, владеть, управлять. Чаще всего в русском языке данный термин употребляется в значении - «управление». Под управлением понимается деятельность, которая направлена на организацию, контроль, анализ и подведение итогов. Управление внутри образовательного учреждения - это целенаправленное взаимодействие участников педагогического процесса.

Изначально менеджмент применялся только к производственной сфере. Претерпевая изменения в своем историческом развитии, последовательно менял направленность в сторону социализации. В настоящее время учет психологических особенностей и развитие потенциала работников организации актуальны для всех организаций. Необходимость в более чутких к «человеческому фактору» формах управления обосновывается переходом от экстенсивных к интенсивным методам хозяйствования.

Американский теоретик П. Ф. Друкер, рассматривая менеджмент, как общественную науку, указывал на то, что данная наука имеет дело с поведением человека, а также с поведением общественных институтов (Друкер, 2004а: 9). Основную задачу менеджмента П. Друкер определял как организацию единых целей и ценностей коллектива, обеспечение развития и повышения квалификации (Друкер, 2004b: 28). По П. Друкеру, менеджмент - это специфический вид деятельности, ориентированной на человека, цель которой - научить людей быть способными к совместным действиям, сделать их усилия эффективными, сгладить присущие им слабости, с учетом того, что человеческая способность вносить вклад в общество зависит не только от собственных усилий и отдачи других, но и от эффективного управления. 
Управленческая и педагогическая деятельности имеют схожие функции: контроль; организационная; мотивационная; информационная; конструктивная функции, а также функция принятия решений.

Объединяющим фактором управленческой и педагогической деятельности стала необходимость изменения действий педагога для реализации управления. Что и привело к формированию нового направления - педагогического менеджмента.

В российской практике в контексте педагогики термин «управление» впервые употребил Н. Н. Иорданский в работе «Школоведение» (Иорданский, 1929). Школоведение стало отраслью советской педагогики и означало процесс организации и управления школьным делом, включая деятельность органов управления. Основными источниками школоведения являлись советское законодательство и опыт управления школами как в СССР, так и за рубежом, педагогическое наследие, выводы и рекомендации (Школоведение, 1978: 427).

В. П. Симонов выделяет педагогический менеджмент в самостоятельную науку, в которой отражена специфика образовательного процесса, как деятельностной системы. Педагогический менеджмент - это управление как учебно-познавательной деятельностью, так и учебновоспитательной (Симонов, 2005: 3).

Внедрение педагогического менеджмента в практику образовательных учреждений РФ необходимо в целях осуществления адекватного управления в условиях меняющегося отечественного образования. Как пишет Л. В, Горюнова, «педагогический менеджмент - управленческая деятельность учителя, осуществляемая в классе и направленная на достижение целей развития личности ребенка, готового к жизни в новых социально-педагогических условиях» (Горюнова, 1999: 15).

Обосновывается данное определение работами советских педагогов. В. А. Сухомлинскоий призывал учителей отказаться от стремления повелевать своими учениками. «Умение управлять уровнем требований личности, стимулировать его повышение, - писал он, - одна из тех сфер педагогического мастерства, где обучение сливается с воспитанием коллектива, где интеллектуальная жизнь коллектива - большая сила, которая обусловливает отношение человека к самому себе и, наконец, побуждает его к самовоспитанию» (Сухомлинский, 1975: 155).

Ю. К. Бабановский считал, что именно педагог совершает переход от управления операциями к управлению действиями, лишь затем - к управлению деятельностью учащихся. Необходимым условием для управления является наличие обратной связи, которая показывает результативность управленческих действий (Бабановский, 1988: 113). 
В своих работах исследователи Т. И. Шамова и Г. Н. Шибанова акцентируют внимание, что любая гуманистическая воспитательная система - это система открытая, важную роль, в которой играет окружающая среда. Особую роль в управлении воспитательной системы занимает деятельность, направленная на реализацию поставленных задач и ориентированную на общечеловеческие ценности. Цель, которую преследует воспитательная система - развитие личности ученика. Цель создания воспитательной системы - реализация педагогической идеи, создание условий для самовыражения участников данной системы. (Шамова, Шибанова, 2005: 15).

Т. И. Шамова также отмечает, что необходима некоторая перестройка преподавателей и руководителей в направлении «принятия приоритета человека во всех звеньях отрасли». Именно гуманные отношения - наиболее важный компонент деятельности и предполагают переход к сотрудничеству от административно-командного подчинения. (Шамова, 2002: 80).

Ю. А. Конаржевский делал акцент на том, что современный поведенческий аспект теории менеджмента ориентирован на человека и социальные ценности, что чрезвычайно важно для образовательных организаций, которые являются «человеческими» (Конаржевский, 2000: 6). Он выделил управленческие принципы, основываясь на позициях педагогического менеджмента, такие как: уважение и доверие к человеку; сотрудничество; целостный взгляд; индивидуальный подход в управлении; личное стимулирование; социальная справедливость; обогащение работы педагога; коллективное принятие решений; консенсус; горизонтальные связи; постоянное обновление; целевая гармонизация; автономизация управления.

В контексте современной теории рассматривается и образовательная среда. Так Ю. С. Мануйлов отмечает необходимость средового подхода как условия реализации, а также на его важность в дополнении к формированию воспитательной среды и ее влияния на личность школьника (Мануйлов, 1997).

Проблема гуманистического и демократического отношения к детям и между людьми в целом, нашла отражение в определении понятия «педагогический менеджмент», предполагающего взаимное уважение и доверие, взаимодействие субъектов образовательного процесса, управление на основе сотрудничества.

Таким образом, педагогический менеджмент определяется как управленческая деятельность учителя или педагога в группе, совокупностью средств, принципов и технологий управления процессами развития личности в педагогической деятельности, а также как наука управления педагогическими процессами. Поскольку система образования представляет 
собой сложную организацию, то и задача менеджера образования (учителя, воспитателя) заключается в создании условий для успешной реализации коллективом целей и задач и задача педагога по формированию умений и навыков конструктивного межличностного взаимодействия.

\section{СПИСОК ЛИТЕРАТУРЫ}

Федеральный закон «Об образовании в Российской Федерации» от 29.12.2012 N 273-Ф3 (последняя редакция) [Электронный ресурс] // Консультант.Плюс. URL: http://www.consultant.ru/document/cons_doc LAW_140174/ (дата обращения: 12.05.2017).

Бабановский, Ю. К. (1988) Педагогика. М. : Просвещение. 197 с.

Школоведение (1978) // Большая Советская Энциклопедия (19691978) / под ред. А. М. Прохорова. Изд. 3-е. М. : Советская энциклопедия. Т. 9.632 с. С. 427.

Горюнова, Л. В. (1999) Овладение знаниями и умениями педагогического менеджмента как фактор повышения качества профессиональной подготовки учителя : дис. ... канд. пед. наук. Ростов н/Д. 239 с.

Друкер, П. Ф. (2004а) Задачи менеджмента в XXI веке / пер. с англ. М. : Издательский дом «Вильямс». 272 с.

Друкер, П. Ф (2004b) Энциклопедия менеджмента / пер. с англ. М. : Издательский дом «Вильямс». 432 с.

Иорданский, Н. Н. (1929) Школоведение. Руководство для массового учителя. Изд. 4-е. М. : «Работник просвещения», 21-я тип. «Мосполиграф». $301 \mathrm{c.}$

Конаржевский, Ю. А. (2000) Менеджмент и внутришкольное управление. М. : Центр «Педагогический поиск». 224 с.

Мануйлов, Ю. С. (1997) Средовой подход в воспитании : дисс.... докт. пед. наук. М. 193 с.

Симонов, В. П. (2005) Диагностика личности и деятельности преподавателя и обучаемых : учеб. пособие. 2-е изд. М. : Изд-во МГОУ. 181 с.

Сухомлинский, В. А. (1975) Мудрая власть коллектива. М. : Молоая гвардия. 204 с.

Шамова, Т.И. (2002) Управление образовательными системами : учебное пособие для вузов. М. : ВЛАДОС. 319 с.

Шамова, Т. И., Шибанова, Г. Н. (2005) Воспитательная системы школы: сущность, содержание, управление. М. : ЦГЛ. 200 с.

Дата поступления: 16.06.2017 2. 
Харченко Елизавета Сергеевна - магистрант кафедры педагогики и психологии высшей школы Московского гуманитарного университета. Адрес: 111395, Россия, г. Москва, ул. Юности, д. 5 Тел.: +7 (499) 374-74-59. Эл. адрес: Ellizabetta5917@mail.ru. Научный руководитель - д-р пед. н., проф. В.А. Ситаров.

Kharchenko Elizaveta Sergeevna, Graduate Student, Department of Pedagogy and Psychology of Higher School, Moscow University for the Humanities. Postal address: 5, Yunosti St., Moscow, Russian Federation 111395. Tel.: +7 (499) 374-74-59. E-mail: Ellizabetta5917@mail.ru. Scientific Adviser - Sitarov V. A., Doctor of Pedagogy, Professor.

\section{Для цитирования:}

Харченко Е. С. Из истории возникновения понятия педагогического менеджмента в России [Электронный ресурс] // Научные труды Московского гуманитарного университета. 2017, № 4. URL: http://journals.mosgu.ru/trudy/article/view/530 (дата обращения: дд.мм.гг.). DOI: 10.17805/trudy.2017.4.7 